\title{
Field Performance of Somaclonal Variants of Plantain (Muss spp., AAB Group)
}

\author{
Dirk R. Vuylsteke', Rony L. Swennen', and Edmond A. De Langhe ${ }^{3}$ \\ Plantain and Banana Improvement Program, International Institute of Tropical Agriculture (IITA), Onne \\ Station, PMB 5320, Ibadan, Nigeria
}

Additional index words. somaclonal variation, tissue culture

\begin{abstract}
Four types of morphologically distinct somaclonal variants were identified in a population of False Horn plantain (Musa spp., AAB group) plants produced by in vitro shoot-tip culture. Field performance of these variants was compared with true-to-type plantain to evaluate their horticultural traits. Significant variation was observed for plant and fruit maturity, leaf size, yield and its components, but not for leaf number, plant height, or suckering. Three of the four somaclonal variants were horticulturally inferior to the original clone from which they were derived. Yields of these variants were very poor due to inflorescence degeneration or abnormal foliage. Only the 'French reversion' variant, which resembled an existing cultivar, outyielded the true-to-type clone. However, its fruit weight and size were lower. Somaclonal variation through micropropagation is of limited use in plantain improvement as it mostly mimics naturally occurring variation along with the observed poor horticultural performance of somaclonal variants.
\end{abstract}

Banana and plantain (Musa spp.) are giant perennial herbs that thrive in the humid tropics. Their fruit provide one of the major commodities in international trade, but are far more important as a starchy staple in local food economies (Stover and Simmonds, 1987). However, production is threatened by pest and disease pressure, which have been increasing during the past 20 years. Most alarming has been the spread of more virulent forms of the fungal diseases black sigatoka leaf spot (Mycosphaerella fljiensis Morelet) and fusarium wilt [Fusarium oxysporum Schlecht. f. sp. cubense (E.F. Smith) Snyd. \& Hans.]. In response to these production constraints, efforts aimed at the genetic improvement of Muss have gained renewed interest (Persley and De Langhe, 1987; Vuylsteke et al., 1993a). Musa germplasm enhancement is, however, burdened with obstacles typical of vegetatively-propagated crops, among which low reproductive fertility and slow propagation are most conspicuous. Hence, biotechnology has been investigated for Musa germplasm handling and improvement (INIBAP, 1993; Novak, 1992; Vuylsteke, 1989).

Application of in vitro culture techniques has significantly improved Musa germplasm handling. Micropropagation using shoottip culture has played a key role in the plantain and banana improvement program of the International Institute of Tropical Agriculture (IITA), Nigeria (Vuylsteke et al., 1993a). Valuable Musa germplasm, including sources of disease and pest resistance, were introduced from all continents using in vitro cultures (Vuylsteke et al., 1990a) and are conserved in vitro (Panis et al., 1990; Vuylsteke, 1989). Large numbers of in vitro plants were produced for rapid establishment of hybridization blocks and for international, multi site hybrid evaluation trials (Vuylsteke et al., 1990b, 1993b).

Received for publication 23 Dec. 1994. Accepted for publication 15 June 1995. We acknowledge the advice of Rodomiro Ortiz (IITA) in statistical analysis, The International Institute of Tropical Agriculture (IITA) is a nonprofit organization and is a member of the Consultative Group on International Agricultural Research (CGIAR). The mailing address is IITA, c/o L.W. Lambourn \& Co., Carolyn House, 26 Dingwall Road, Croydon CR9 3EE, U.K. The cost of publishing this paper was defrayed in part by the payment of page charges. Under postal regulations, this paper therefore must be hereby marked advertisement solely to indicate this fact. 'Tissue culturist and germplasm enhancer. Current address: IITA, P.O. Box 7878, Kampala, Uganda.

${ }^{2}$ Agronomist/breeder. Current address: Laboratory of Tropical Crop Husbandry, Katholieke Universiteit Leuven, Kardinaal Mercierlaan 92,3001 Heverlee, Belgium. ${ }^{3}$ Professor emeritus. Current address: Laboratory of Tropical Crop Husbandry, Katholieke Universiteit Leuven, Kardinaal Mercierlaan 92,3001 Heverlee, Belgium.
However, some plants regenerated from in vitro culture have exhibited various morphological and biochemical variations due to genetic changes that Larkin and Scowcroft (1981) termed somaclonal variation. In Musa, plants produced by shoot-tip culture have shown somaclonal variation rates of $0 \%-70 \%$, mainly depending on the genotype (Smith, 1988; Vuylsteke et al., 1991). Frequent use of shoot cultures for Musa germplasm handling and improvement warrants investigation into the occurrence of somaclonal variation in this genus. Qualitative aspects of somaclonal variation in Muss have been documented to a reasonable extent (Israeli et al., 1991; Smith, 1988; Vuylsteke et al., 1991), but quantitative variation has been less characterized. Some work has been done on field evaluation of somaclonal variants in micropropagated dessert bananas (Musa spp., AAA group) of the 'Cavendish' subgroup (Hwang and Ko, 1987; Israeli et al., 199 I; Smith and Drew, 1990; Stover, 1987, 1988). Variants in plant stature (e.g., dwarfs), foliage, and pseudostem pigmentation were observed. Variants were mostly inferior to the 'Cavendish' clone from which they were derived, in that bunch and fruit of the variants were smaller and of little or no commercial value (Hwang and Ko, 1987; Smith and Drew, 1990; Stover, 1987). Hwang and Ko (1987) identified somaclonal variants with putative field resistance to fusarium wilt, but all had inferior horticultural characteristics.

Very little work has been done on the field performance of somaclonal variants of plantain. Only Ramcharan et al. (1987) reported on the field performance of one off-type of each of two plantain clones. Here, we describe the horticultural performance of a wider range of somaclonal van ants that were obtained in micropropagated plantings of a common plantain cultivar and evaluate their usefulness in plantain improvement.

\section{Materials and Methods}

Micropropagated plants of plantain cultivar Agbagba, a medium 'False Horn' plantain widely cultivated under different names (Swennen, 1990; Swennen and Vuylsteke, 1987), were produced following standard shoot-tip culture (Vuylsteke, 1989). Aseptic cultures were initiated from lateral buds collected from field-grown plants known to be true-to-type for two successive production cycles. Buds were washed in running water for $30 \mathrm{sec}$ followed by a rinse in $70 \%$ ethanol for 1 rein, surface disinfected in commercial bleach (10\% Clorox) for 15 rein, and rinsed in sterilized, distilled water. 
Shoot tips about $1 \mathrm{~cm}$ tall were excised aseptically and cultured onto a $20 \mathrm{ml}$ shoot proliferation medium in $150 \times 25-\mathrm{mm}$ culture tubes. The medium consisted of modified Murashige and Skoog (1962) (MS) medium supplemented with $10 \mathrm{mg} \cdot \mathrm{liter}^{-1}$ ascorbic acid, 0.18 $\mathrm{mg} \cdot$ liter $^{-1}$ indole-3-acetic acid (IAA), $4.5 \mathrm{mg} \cdot \operatorname{liter}^{-1}$ 6-benzyladenine (BA), and solidified with $4.5 \mathrm{~g} \cdot \operatorname{liter}^{-1}$ agar (Oxoid, Unipath Ltd., Basingstoke, England) at $\mathrm{pH}$ 5.8. The culture medium was autoclave for $15 \mathrm{~min}$ at $121 \mathrm{C}(103.4 \mathrm{kpa})$. Multiplication of shoot-tip cultures through serial subcultures every 2 months produced 965 plantlets (Vuylsteke et al., 1988). Rooting of proliferating shoots was achieved by placing small clusters of two to three shoots/buds on the same MS medium, but without IAA and with $0.19 \mathrm{mg} \cdot \operatorname{liter}^{-1} \mathrm{I}$ naphthaleneacetic acid (NAA) and $0.23 \mathrm{mg} \cdot \operatorname{liter}^{-1} \mathrm{BA}$. All cultures were maintained in a culture room at $27-32 \mathrm{C}$ on a $14-\mathrm{h}$ photoperiod with light provided by $40-\mathrm{W}$ cool-white fluorescent tubes. Rooted plantlets were transferred to a nursery shed for acclimatization for 2 months before planting in the field.

The trial was planted in the rainy season of 1985 at the Onne station near Port Harcourt (southeastern Nigeria) at the International Institute of Tropical Agriculture (IITA), which is in the humid forest zone of western Africa. The soil was a deep, well-drained Typic Paleudult derived from coastal sediments (Niger Delta region), which is poor in nutrients and is highly acidic ( $\mathrm{pH}$ 4.2). Annual rainfall averaged $2400 \mathrm{~mm}$ from February to December (monomodal). Plants were spaced at $3 \times 2 \mathrm{~m}$, providing a density of 1667 plants/ha. Plants were fertilized at the rate of $300 \mathrm{~kg} \mathrm{~N}$ and $450 \mathrm{~kg} \mathrm{~K} / \mathrm{ha}$ per year split over six equal applications during the rainy season, using urea and muriate of potash, respectively. The field was completely covered with mulch of Pennisetum purpureum Schum. as recommended by Swennen (1990). Plants were treated with an insecticide/nematicide consisting of $2 \mathrm{~g}$ of the active ingredient carbofuran per plant and applied every 4 months to the soil around the stem to control banana weevil and nematodes.

Characteristics of individual 'Agbagba' plants were assessed by measuring growth and yield variables according to Swennen and De Langhe (1985) and Swennen and Vuylsteke ( 1987) over two production cycles (plant crop and first ratoon). Screening for phenotypic variation was performed by monitoring typical morphological descriptors of plantain (Tezenas du Montcel et al., 1983). Five stable variant phenotypes, totalling $6 \%$ of the micropropagated plantain population, were identified and have been described morphologically (Vuylsteke et al., 1988, 1991). Two variants had off-type inflorescence morphology ( 'French reversion' and 'Monganga-type' ) and three exhibited abnormal foliage (distorted leaves, drooping leaves, and leaf variegation).

All flowering plants of somaclonal variants were used for data collection. Twenty-four plants of 'French reversion', three plants of 'Monganga-type' and six plants of the 'distorted leaves' variants were monitored over two production cycles. Eleven plants of the drooping leaves variant were observed only during the plant crop cycle as they failed to produce a second cycle within three years. A single plant showing leaf variegation never flowered and, therefore, was not included in the analysis. Forty-four plants, i.e., the same number as the number of plants from the observed somaclonal variants, were randomly selected from the 907 true-to-type "Agbagba" plants. As somaclonal variants occurred randomly in the field, the experimental layout was considered to be a completely randomized design with single plant replications. Statistical analysis of data on growth and yield variables in cv. 'Agbagba' and its four somaclonal variants was performed with the NONORTHO subprogram of MSTAT-C software (MSU, 1990). ANOVA was done using genotypes $(\mathrm{G})$, production cycles $(\mathrm{C})$ and $\mathrm{G} \times \mathrm{C}$ interaction as sources of variation.

\section{Results and Discussion}

A significant genotype $\times$ cycle interaction was observed for most vegetative growth variables, resulting in the lack of significant genotypic differences for plant height and height of the tallest sucker (follower for the first ratoon) at flowering and harvest of the main pseudostem (Table 1). Conversely, most yield variables did not show interaction (Table 2). Where the $\mathrm{G} \times \mathrm{C}$ interaction was significant, the mean square of $\mathrm{G} \times \mathrm{C}$ (instead of the mean square of error) was used to determine the significance of genotype and cycle effects (Tables 1 and 2) and to calculate LSD (Tables 3 and 4). Cycle effects were significant for most growth variables, yield (i.e., bunch weight), and fruit weight (Tables 1 and 2). Plants were generally longer and with longer suckers, while yield and fruit weight were lower in the second cycle (first ratoon) compared to the first cycle (plant crop) (data not shown). These may be considered normal cycle effects in plantain. Significant variation among genotypes was observed for plant and fruit maturity (i.e., time from planting to flowering and from flowering to harvest, respectively), leaf size (length and width), and all yield and bunch parameters (Tables 1 and 2).

Among somaclonal variants, the two inflorescence-type variants closely resembled other existing plantain cultivars and were designated 'French reversion' (25 plants) and 'Monganga-type' (3 plants). The former variant produced an inflorescence typical of the 'French' plantain, which differs from the original 'False Horn' plantain in having a complete inflorescence with many relatively small fruits, many persistent intermediate flowers, and a male bud present at maturity (Tezenas du Montcel et al., 1983; Vuylsteke et al., 1988). The 'Monganga-type' variant produced a more degenerated 'False Horn' inflorescence, resembling 'Monganga' as described by De Langhe (1961). These two inflorescence-type variants, together with the original 'Agbagba' clone, actually represent typical steps in the "plantain inflorescence degeneration line", a phrase used to describe the phenomenon of continuous variation from complete ('French' plantains) to incomplete ('False Horn' and 'Hem' plantains) inflorescences in the plantain germplasm (De Langhe, 1961; Swennen and Vuylsteke, 1987; Tezenas du Montcel et al., 1983; Vuylsteke et al., 1991). The three foliage variants showed either drooping leaves $(22$

Table 1. F tests of the analysis of variance for growth parameters of micropropagated plants of the False Horn plantain (Musa spp,, AAB group) 'Agbagba' and its somaclonal variants over two production cycles.

\begin{tabular}{|c|c|c|c|c|c|c|c|c|c|c|}
\hline \multirow{2}{*}{$\begin{array}{l}\text { Source of } \\
\text { variation }\end{array}$} & \multicolumn{3}{|c|}{ Days to } & \multirow{2}{*}{$\begin{array}{l}\text { Total no. } \\
\text { of leaves }\end{array}$} & \multirow{2}{*}{$\begin{array}{c}\text { Plant } \\
\text { ht }(\mathrm{cm})\end{array}$} & \multicolumn{2}{|c|}{ Length of longest sucker at } & \multicolumn{3}{|c|}{ Leaf } \\
\hline & Flowering & Fruit filling & Harvest & & & Flowering $(\mathrm{cm})$ & Harvest $(\mathrm{cm})$ & Length $(\mathrm{cm})$ & Width $(\mathrm{cm})$ & Ratio \\
\hline$\overline{\text { Cycles }(\mathrm{C})^{2}}$ & NS & $* *$ & NS & **** & **** & $* *$ & $*$ & --- & --- & --- \\
\hline Genotypes $(\mathrm{G})^{2}$ & $*$ & $* * *$ & $*$ & NS & NS & NS & NS & $* * *$ & $* * *$ & $* * *$ \\
\hline $\mathrm{C} \times \mathrm{G}$ & $* *$ & NS & $* *$ & NS & $* *$ & $*$ & $*$ & $\cdots$ & --- & $-\cdots$ \\
\hline $\mathrm{CV}(\%)$ & 20.2 & 7.9 & 15.7 & 7.2 & 6.0 & 43.3 & 51.2 & 5.0 & 4.5 & 5.4 \\
\hline
\end{tabular}

${ }^{\overline{ }} \mathrm{F}$ test was conducted using mean square of $\mathrm{C} \times \mathrm{G}$ as denominator when $\mathrm{C} \times \mathrm{G}$ interaction was significant.

Ns $, * * *, * * *$ Nonsignificant or significant Fat $\mathrm{P} \leq 0.05,0.01$, or 0.001 , respectively. 
Table 2. F tests of the analysis of variance for yield and bunch parameters of micropropagated plants of the 'False Horn' plantain (Musa spp., AAB group) 'Agbagba' and its somaclonal variants over two production cycles.

\begin{tabular}{|c|c|c|c|c|c|c|c|}
\hline \multirow{2}{*}{$\begin{array}{l}\text { Source } \\
\text { of } \\
\text { variation }\end{array}$} & \multirow{2}{*}{$\begin{array}{c}\text { Bunch } \\
\text { wt } \\
(\mathrm{kg})\end{array}$} & \multirow{2}{*}{$\begin{array}{l}\text { No. of } \\
\text { hands/ } \\
\text { bunch }\end{array}$} & \multirow{2}{*}{$\begin{array}{l}\text { No. of } \\
\text { fruit/ } \\
\text { bunch }\end{array}$} & \multirow{2}{*}{$\begin{array}{l}\text { Avg no. } \\
\text { of fruit/ } \\
\text { hand }\end{array}$} & \multicolumn{2}{|c|}{ Fruit wt $(\mathrm{g})$} & \multirow{2}{*}{$\begin{array}{c}\text { No. of } \\
\text { intermediate } \\
\text { hands }\end{array}$} \\
\hline & & & & & Avg & $\begin{array}{c}\text { Of first } \\
\text { hand }\end{array}$ & \\
\hline$\overline{\text { Cycles }(C)^{\prime}}$ & $* * *$ & NS & NS & NS & ***k & $* * * *$ & NS \\
\hline Genotypes $(\mathrm{G})^{\prime}$ & $* * * *$ & $*$ & 水**; & *水水 & 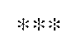 & $* * * *$ & $* * * *$ \\
\hline $\mathrm{C} \times \mathrm{G}$ & NS & $*$ & NS & NS & NS & NS & NS \\
\hline $\mathrm{CV}(\%)$ & 22.6 & 13.5 & 16.7 & 12.8 & 20.6 & 22.4 & 25.4 \\
\hline
\end{tabular}

${ }^{2} \mathrm{~F}$ test was conducted using mean square of $\mathrm{C} \times \mathrm{G}$ as denominator when $\mathrm{C} \times \mathrm{G}$ interaction was significant.

ss $, *, * *, * * *$ Nonsignificant or significant $\mathrm{F}$ at $P \leq 0.05,0.01$, or 0.001 , respectively.

Table 3. Main genotype effects for growth parameters of micropropagated plants of the "False Horn' plantain (Musa spp., AAB group) 'Agbagba' and its somaclonal variants over two production cycles. Number of observations are in brackets.

\begin{tabular}{|c|c|c|c|c|c|c|c|c|c|c|}
\hline \multirow[b]{2}{*}{ Genotype } & \multicolumn{3}{|c|}{ Days to } & \multirow[b]{2}{*}{$\begin{array}{l}\text { Total no, } \\
\text { of leaves }\end{array}$} & \multirow{2}{*}{$\begin{array}{c}\text { Plant } \\
\mathrm{ht} \\
(\mathrm{cm})\end{array}$} & \multicolumn{2}{|c|}{ Length of longest sucker at } & \multicolumn{3}{|c|}{ Leaf } \\
\hline & Flowering & $\begin{array}{l}\text { Fruit } \\
\text { filling }\end{array}$ & Harvest & & & $\begin{array}{l}\text { Flowering } \\
(\mathrm{cm})\end{array}$ & $\begin{array}{l}\text { Harvest } \\
(\mathrm{cm})\end{array}$ & $\begin{array}{l}\text { Length } \\
(\mathrm{cm})\end{array}$ & $\begin{array}{l}\text { Width } \\
\text { (cm) }\end{array}$ & Ratio \\
\hline \multicolumn{11}{|c|}{ True-to-type } \\
\hline Agbagba & $267(87)$ & $90(87)$ & $356(87)$ & $32(87)$ & $368(87)$ & $87(87)$ & $124(86)$ & $225(44)$ & $83(44)$ & $2.73(44)$ \\
\hline \multicolumn{11}{|c|}{ Off-rypes } \\
\hline French reversion & $302(44)$ & $96(39)$ & $395(39)$ & $32(44)$ & $364(44)$ & $70(43)$ & $87(44)$ & $230(24)$ & $84(24)$ & $2.76(24)$ \\
\hline Monganga-type & $277(6)$ & $79^{\prime \prime}(6)$ & $355(6)$ & $33(6)$ & $355(6)$ & $64(6)$ & $157(6)$ & $217(3)$ & $81(3)$ & $2.63(3)$ \\
\hline Distorted laminas & $362(10)$ & $80^{*}(7)$ & $420(7)$ & $33(10)$ & $398(10)$ & $25(10)$ & $40(10)$ & $169(2)$ & $49(2)$ & $3.49^{\circ}(2)$ \\
\hline Drooping leaves & $553^{*}(11)$ & $76(11)$ & $629^{*}(11)$ & $31(11)$ & $301(11)$ & $33(11)$ & $72(11)$ & $170^{\prime \prime}(10)$ & $58^{*}(10)$ & $2.93^{*}(10)$ \\
\hline$\left(\mathrm{t}_{0,0,0} \times \sqrt{\mathrm{MS}}\right)^{\prime}$ & 429 & 14 & 418 & NS & NS & NS & NS & 22 & 7 & 0.30 \\
\hline
\end{tabular}

${ }^{2} \mathrm{MS}=$ mean square of error when $\mathrm{C} \times \mathrm{G}$ interaction was not significant (see Table 1):otberwisc the mean square of $\mathrm{C} \times \mathrm{G}$ was used. Calculate LSD 0 s by multiplying this value with $\sqrt{ } \mid / \mathrm{n} l+1 / \mathrm{n} 2$.

*Significantly different from the true-to-type "Agbagba at $P=0.05$ using LSD for single pair comparison within columns.

plants), distorted leaves (7 plants) or leaf variegation (1 plant) (Vuylsteke et al., 1988).

Growth variables. Somaclonal variants matured later than trueto-type 'Agbagba' plants as measured by days from planting to flowering (i.e., bunch emergence) and/or harvest. However, the difference was only significant for the 'drooping leaves' variant (Table 3). This variant was extremely slow-growing, whereas the other variants had a similar growth rate as normal 'Agbagba' plants. Nevertheless, the 'distorted leaves' variant was also slower to flower. Nine months after planting, none of the 'distorted leaves' and 'drooping leaves' variants had flowered, whereas more than $50 \%$ of the true-to-type plants and of the 'French reversion' and 'Mongangatype' variants were already flowering. While the 'distorted leaves' variant did not mature later than 'Agbagba' over the two cycles, a significant difference in the second production cycle was observed whereby the variant was harvested six months later in the first ratoon (522 vs. 350 days, respectively). The 'French' variant matured one month later than true-to-type 'Agbagba'. Although this difference was not significant in our study, Ramcharan et al. (1987) observed the same difference in plant maturity.

All somaclonal variants were significantly different from the original clone for fruit maturation time, as determined by the number of days from flowering to harvest, i.e., days for fruit filling (Table 3). Harvest time was recorded beginning from the day the first fruit, also called a finger. turned from green to partly yellow. The 'French reversion' variant had a longerfruit maturation time, while fruit of the three other variants matured 10-14 days earlier than the original clone. Ramcharan et al. ( 1987) also observed that the 'French' offtypes required more time to reach fruit maturity than 'False Horn'.

The total number of leaves produced from planting to flowering (at which time leaf production on the main stem stops) was the same for all genotypes (Table 3). This is directly related to plant stature, which, together with inflorescence morphology, are the main morphotaxonomic criteria in plantain. Plant stature is commonly classified into three groups based on number of leaves: giant plantains producing > 38 leaves/plant, medium plantains producing 3234 leaves/plant, and small plantains with $<32$ leaves/plant (Swennen and Vuylsteke, 1987: Tezenas du Montcel et al., 1983). All somaclonal variants obtained belonged to the same medium-sized category as the true-to-type 'Agbagba'.

Due to a significant $\mathrm{G} \times \mathrm{C}$ interaction for plant height at flowering (Table I), no significant differences among genotypes over the two production cycles were obtained (Table 3). However, in the plant crop cycle, the 'drooping leaves' variant was significantly shorter $(301 \mathrm{~cm})$ and the 'distorted leaves' variant longer $(393 \mathrm{~cm})$ than the true-to-type plants $(337 \mathrm{~cm})$. Plant height of 'French reversion' (339 $\mathrm{cm})$ and 'Monganga-type' $(327 \mathrm{~cm})$ variants were similar to that of 'Agbagba', suggesting that changes in inflorescence morphology did not affect plant height.

Although large differences in sucker growth among genotypes were observed, these were not significant due to significant $\mathrm{G} \times \mathrm{C}$ interaction and high coefficients of variation (Tables 1 and 3 ). Therefore, height of the longest sucker at harvest was also analyzed using data of the plant crop only, and significant differences were observed. The 'Monganga-type' variant had longer suckers (137 $\mathrm{cm})$, whereas the 'French reversion' $(66 \mathrm{~cm})$ and 'distorted leaves' $(48 \mathrm{~cm})$ variants had shorter suckers than true-to-type plants $(86 \mathrm{~cm})$. Sucker height of the 'drooping leaves' variant $(72 \mathrm{~cm})$ was not different from 'Agbagba'. Plantains generally exhibit poor sucker development as a result of high apical dominance (Swennen and De Langhe, 1985). It is likely that the 'French reversion' and 'distorted leaves' off-types have an even stronger apical dominance, which may have a negative influence on perennial productivity. 
Table 4. Main genotype effects for yield and bunch parameters of micropropagated plants of the 'False Horn' plantain (Musa spp., AAB group) 'Agbagba' and its somaclonal variants over two production cycles, Number of observations are in brackets.

\begin{tabular}{|c|c|c|c|c|c|c|c|}
\hline \multirow[b]{2}{*}{ Genotype } & \multirow{2}{*}{$\begin{array}{c}\text { Bunch } \\
\text { wt } \\
(\mathrm{kg})\end{array}$} & \multirow{2}{*}{$\begin{array}{l}\text { No. of } \\
\text { hands/ } \\
\text { bunch }\end{array}$} & \multirow{2}{*}{$\begin{array}{l}\text { No. of } \\
\text { fruit/ } \\
\text { bunch }\end{array}$} & \multirow{2}{*}{$\begin{array}{l}\text { Avg no. of } \\
\text { fruit/ } \\
\text { hand }\end{array}$} & \multicolumn{2}{|c|}{ Fruit wt (g) } & \multirow{2}{*}{$\begin{array}{c}\text { No. of } \\
\text { intermediate } \\
\text { hands }\end{array}$} \\
\hline & & & & & Avg & $\begin{array}{c}\text { Of } \\
\text { first hand }\end{array}$ & \\
\hline \multicolumn{8}{|c|}{ True-to-type } \\
\hline \multicolumn{8}{|c|}{ Off-types } \\
\hline French reversion & $14.4 *(38)$ & $6.9^{*}(44)$ & $84^{*}(44)$ & $12.2^{*}(44)$ & $170^{*}(38)$ & $190^{\circ}(36)$ & $73^{*}(32)$ \\
\hline Monganga-type & $3.2^{*}(6)$ & $4.0^{*}(6)$ & $10^{*}(6)$ & $2.8(6)$ & $310(6)$ & $274(6)$ & $1^{*}(6)$ \\
\hline Distorted laminas & $3.8^{*}(7)$ & $6.3^{*}(10)$ & $14^{*}(10)$ & $2.2(10)$ & $250^{*}(7)$ & $252^{*}(7)$ & $2^{*}(8)$ \\
\hline Drooping leaves & $2.7^{*}(11)$ & $4.4^{*}(11)$ & $13^{*}(11)$ & $3.0^{*}(11)$ & $218^{*}(11)$ & $203^{k}(11)$ & $7^{*}(11)$ \\
\hline$\left(\mathrm{t}_{0.05} \times \sqrt{\mathrm{MSS}}\right)^{\gamma}$ & 4.8 & 5.5 & 15 & 2 & 108 & 116 & 13 \\
\hline
\end{tabular}

${ }^{2} \mathrm{MS}=$ mean square of error when $\mathrm{C} \times \mathrm{G}$ interaction was not significant (see Table 2): otherwise the mean square of $\mathrm{C} \times \mathrm{G}$ was used. Calculate $\mathrm{LSD}_{0.05}$ by multiplying this value with $\sqrt{ } 1 / \mathrm{n} 1+1 / \mathrm{n} 2$.

*Significantly different from the true-to-type 'Agbagba' at $\mathrm{P}=0.05$ using LSD for single pair comparison within columns.

Significant genotypic differences were observed for leaf size components (Table 1), but the two foliage variants accounted for most of this variation (Table 3). Vuylsteke et al. (1988) already described the grossly abnormal foliage structure of' the 'drooping leaves' and 'distorted leaves' variants, which are characterized by short and narrow leaves that results in a significantly higher leaf ratio.

Yield variables. Plantain yield is commonly determined by fresh bunch weight and plant density. 'Agbagba' bunches weighed $11.3 \mathrm{~kg}$, which is an average bunch weight for this cultivar at the experimental site (Swennen and Vuylsteke, 1987), and produced a yield of 18.8 tons/ha per year. There were significant differences in bunch weight among genotypes, with three of the four variants yielding very poorly (Tables 2 and 4). Only the 'French reversion' variant outyielded (by 27\%) the standard clone. The higher yield of the 'French' variant was solely a function of the greater number of fruits per hand and per bunch, as number of hands and fruit weight were significantly lower than in the 'False Horn' clone (Table 4). Ramcharan et al. ( 1987) observed the same trend, but differences in yield and number of fruits per bunch between the 'French' off-type and the original 'False Horn' plantain were larger. Whereas the 'French reversion' variant is high-yielding, several negative factors impinge on its yield advantage. With fruit weight significantly lower, it is known that the fruit's pulp/peel ratio is lower. Also, traditional plantain consumers generally prefer the longer and bigger fruit of the 'False Horn' plantains. The delayed plant and fruit maturity of the 'French reversion' are also less preferred horticultural qualities.

The 'Monganga-type' variant, which had a more degenerated inflorescence than 'Agbagba' (Vuylsteke et al., 1988), yielded poorly due to a significant reduction in the number of hands and fruits per bunch, but had a high fruit weight typical of the 'False Horn' plantains (Table 4). Its inflorescence degeneration was further emphasized by the reduction in the average number of fruits per hand and in the number of intermediate hands (i.e., hands bearing nonparthenocarpic flowers).

The observed differences in yield and its components among the 'French reversion', 'Agbagba', and 'Monganga-type' clones are typical of the natural variation between the 'French' and 'False Horn' plantain gene pools (Swennen and Vuylsteke, 1987; Tezenas du Montcel et al., 1983). It is inferred that the most common somaclonal variation in plantain, i.e., change in inflorescence morphology, mimics naturally occurring variation in both qualitative descriptors (Vuylsteke et al., 1991) and quantitative traits.

Against the same clonal background, it is noteworthy to highlight the salient features of the quantitative trait variation associ- ated with the plantain inflorescence degeneration as recovered through somaclonal variation. That bunch weight and number of fruits decreases, but fruit weight increases while progressing from the 'French' to the 'False Horn' bunch type was expected (Swennen and Vuylsteke, 1987), and was only confirmed with the results presented here. We observed that fruit maturation time is correlated with number of fingers in a bunch (Tables 3 and 4). Shorter fruit maturation times were observed in the variants with fewer fingers (e.g., 'Monganga-type' ), and vice versa ('French reversion'). Less fruits per plant may require less time to fill with dry matter, resulting in earlier fruit maturity. The 'French' plantain also has delayed plant maturity, higher apical dominance (at least in the plant crop), and less hands per bunch than the 'False Horn' type. These trends in quantitative trait variation between 'French' and 'False Horn' plantains were recently corroborated by the results of a 6 year old trial in which the main taxonomic groups of plantain were evaluated for their perennial yield potential (IITA, unpubl. results). Plant height and leaf size did not change with inflorescence type variation, indicating that the off-type of a medium-sized plantain clone was a medium-sized variant.

The variants with drooping leaves and distorted leaves had greatly reduced yields when compared to true-to-type 'Agbagba' (Table 4). All yield components (number of hands, number of fruits, and fruit weight) were significantly lower, but the reduction in number of fruits contributed most to reduced yield. Inflorescences of the foliage variants were also more degenerated than in 'Agbagba', as indicated by the low average number of fruits per hand and low number of intermediate hands (Table 4). The two foliage variants were clearly inferior genotypes as their aberrant foliage structure and architecture negatively affected productivity.

In conclusion, somaclonal variants of the typical and widespread 'False Horn' plantain CV. 'Agbagba' can be distinguished from true-to-type plants by their variant leaf and inflorescence morphology (Vuylsteke et al., 1988, 1991). In terms of quantitative trait variation, differences occurred mainly in yield and bunch parameters and in fruit maturity (Tables 3 and 4). The two foliage variants also differed from true-to-type plantain in leaf size and plant maturity (Table 3). There was no significant variation in plant height and in the total number of leaves, underscoring the absence of dwarf or giant variants. In the numerous plantings of micropropagated plantains, we never observed dwarfism and gigantism (Vuylsteke et al., 1991), which occur frequently in micropropagated 'Cavendish' bananas (Israeli et al., 199 1; Smith and Drew, 1990; Stover, 1988), although there have been reports of their occurrence in plantain (Sandoval et al., 1991). 
We reiterate that somaclonal variants derived through micropropagation are of little use as a source of useful variability for plantain improvement (Vuylsteke et al., 1991). The range of somaclonal variants recovered through shoot-tip culture is narrow and mostly mimics naturally occurring variation. The horticultural performance of somaclonal variants is generally inferior to that of the original clone from which they were derived. The overall poor yield of off-types is limiting the expansion in use of in vitro plants, which otherwise have many advantages and are particularly useful when a new genotype is being introduced. This has been demonstrated with the commercially important dessert banana cultivars of the 'Cavendish' subgroup, in which most somaclonal variants are also horticulturally inferior to the original clone (Daniells and Smith, 1993; Hwang and Ko, 1987; Smith and Drew, 1990; Stover, 1987). Some off-types may have beneficial traits, such as the higher yield of the 'French reversion' variant in plantain, the short stature of dwarfs, and the lower fusarium wilt incidence in variants of 'Cavendish' banana, but these changes are always associated with problems in fruit size and quality (Hwang et al., 1993; Stover, 1987). Large-scale surveys of somaclonal variants of banana and plantain did not indicate any increase in resistance to the sigatoka leaf spot diseases (Stover, 1987; Vuylsteke et al., 1991). The field resistance to fusarium wilt of somaclonal variants recovered in Taiwan (Hwang and Ko, 1987; Hwang et al., 1993) could not be confirmed when tested in other locations and maybe flawed by the lack of a reliable screening technique. Because the somaclonal variation derived through shoot micropropagation may only represent a fraction of the variation that could be generated through regeneration from cell and protoplasm cultures from different explants, the full potential of somaclonal variation for plantain and banana improvement remains to be explored. Nevertheless, recent advances in the genetic improvement of Muss by conventional and gene transfer methods (Panis et al., 1993; Vuylsteke et al., 1993b) suggest that such targeted approaches hold much more promise than somaclonal variation.

\section{Literature Cited}

Daniells, J.W. and M.K, Smith, 1993. Somatic mutations of bananas - Theirstability and potential, p. 162-1 71. In: R.V. Valmayor, S.C. Hwang, R. Ploetz, S.W. Lee, and N.V. Roa (eds.). Recent developments in banana cultivation technology. Proc. Intl. Symp., Chiuju, Pingtung, Taiwan, 14-18 Dec. 1992. Intl. Network for the Improvement of Banana and Plantain, Los Barlos, Laguna, Philippines,

De Langhe, E. 1961. La taxonomie du bananier plantain en Afrique équatoriale. J. Agr. Trop. Bet. Appl. 8:417-449.

Hwang, S.C. and W.H. Ko. 1987. Somaclonal variation of bananas and screening for resistance to Fusarium wilt, p. 151-156. In: G.J. Persley and E.A. De Langhe (eds.). Banana and plantain breeding strategies. Proc. Intl. Wkshp., Cairns, Austral., 1317 Oct. 1986, ACIAR Pmt. No. 21, Austral. Cent. Intl. Agr. Res., Canberra.

Hwang, S. C., W.H. Ko, and C. P. Chao. 1993, GCTCV-21 5-1: A promisingCavendish clone resistant to race 4 of Fusarium oxysporum f.sp. cubense, p. 62-74, In: R.V. Valmayor, S.C. Hwang, R. Ploetz, S.W. Lee, and N.V. Roa (eds.), Recent developments in banana cultivation technology. Pmt. Intl, Symp., Chiuju, Pingtung, Taiwan, 14-18 Dec. 1992, Intl. Network for the Improvement of Banana and Plantain, Los Bafios, Laguna, Philippines,

INIBAP. 1993. Biotechnology applications for banana and plantain improvement, Proc. Wkshp., San José, Costa Rica, 27-31 Jan. 1992. Intl. Network for the Improvement of Banana and Plantain, Montpelier, France.

Israeli, Y., O. Reuveni, and E. Lahav. 1991. Qualitative aspects of somaclonal variation in banana propagated by in vitro techniques. Scientia Hort. 48:71-88.

Larkin, P.J. and W.R. Scowcroft. 1981. Somaclonal variation-A novel source of variability from cell culture for plant improvement. Theor. Appl. Genet. 58:197214.

MSU. 1990. MSTAT-C. A microcomputer program for the design, management, and analysis of agronomic research experiments. Michigan State Univ., East Lansing, Mich.
Murashige, T. and F. Skoog. 1962, A revised medium for rapid growth and bioassays with tobacco tissue cultures. Physiol. Plant. 15:473-497.

Novak, F.J. 1992, Musa (bananas and plantains), p. 449-488. In: F.A. Hammerschlag and R.E. Litz(eds.), Biotechnology of perennial fruit crops. C.A.B. Intl., Wallingford, UK.

Panis, B., L. Withers, and E. De Langhe. 1990. Cryopreservation ofMusa suspension cultures and subsequent regeneration of plants. Cry-letters 11:337-350.

Panis, B., D. Dhed'a, K. De Smet, L. Sagi, B. Cammue, and R. Swennen. 1993, Cell suspensions from somatic tissue in Muss: Applications and prospects, p. 317-325, In: J. Ganry (ed.). Breeding banana and plantain for resistance to diseases and pests. Proc. Intl. Symp., Montpelier, France, 7-9 Sept. 1992. Centre de coopération international en recherche agronomique pour le développement (CIRAD), Montpelier, France.

Persley, G.J, and E.A. De Langhe (eds.). 1987, Banana and plantain breeding strategies. Proc. Intl. Wkshp., Cairns, Austral., 13-17 Oct. 1986. ACIAR Proc. No. 21. Austral. Cent. Intl. Agr. Res., Canberra,

Ramcharan, C., A. Gonzalez, and W.I, Knausenberger. 1987. Performance of plantains produced from tissue-cultured plantlets in St. Croix, U.S. Virgin Islands, p. 36-39. In: International cooperation for effective plantain and banana research. Proc. 3rd IARPB meeting, Abidjan, Côte d'Ivoire, 27-31 May 1985. Intl. Network for the Improvement of Banana and Plantain, Montpelier, France.

Sandoval, J., A. Tapia, L. Müller, and V. Villalobos, 1991. Observaciones sobre la variabilidad encontrada en plantas micropropagadas de Musa cv. 'Falso Cuerno' AAB. Fruits 46: 533-539,

Smith, M.K. 1988. A review of factors influencing the genetic stability of micropropagated bananas. Fruits 43:219-223.

Smith, M.K. and R.A. Drew. 1990. Growth and yield characteristics of dwarf offtypes recovered from tissue-cultured bananas. Austral. J. Expt. Agr, 30: 575-578.

Stover, R.H. 1987. Somaclonal variation in Grand Naine and Saba bananas in the nursery and field, p. 136-139. In: G.J. Persley and E.A. De Langhe (eds.). Banana and plantain breeding strategies. Pmt. Intl. Wkshp., Cairns, Austral., 13-17 Oct. 1986, ACIAR Pmt. No, 21. Austral. Cent. Intl. Agr. Res., Canberra.

Stover, R.H. 1988, Variation and cultivar nomenclature in Musa, AAA group, Cavendish subgroup. Fruits 43:353-357.

Stover, R.H. and N.W. Simmonds. 1987. Bananas. 3rd ed. Longman, Essex, England. Swennen, R. 1990. Plantain cultivation under West African conditions. A reference manual. Intl. Inst. Trop. Agr., Ibadan, Nigeria.

Swennen, R. and E. De Langhe. 1985, Growth parameters of yield of plantain(Musa cv. AAB). Ann. Bot. 56: 197-204.

Swennen, R. and D. Vuylsteke. 1987, Morphological taxonomy of plantain (Musa cultivars AAB) in West Africa, p. 165-171. In: G.J. Persley and E.A. De Langhe (eds.). Banana and plantain breeding strategies. Proc. Intl. Wkshp., Cairns, Austral., 13-1 7 Oct. 1986. ACIAR Proc. No. 21. Austral. Cent. Intl. Agr. Res., Canberra.

Tezenas du Montcel, H., E. De Langhe, and R. Swennen. 1983. Essai declassification des bananiers plantain (AAB). Fruits 38:461-474.

Vuylsteke, D. 1989. Shoot-tip culture for the propagation, conservation, and ex change of Musa germplasm, Practical manuals for handling crop germplasm in vitro 2. Intl. Board for Plant Genet. Resources, Rome.

Vuylsteke, D., R. Swennen, G.F. Wilson, and E. De Langhe. 1988, Phenotypic variation among in vitro propagated plantain (Musa spp. cv. AAB). Scientia Hint. 36:79-88.

Vuylsteke, D., J. Schoofs. R. Swennen, G. Adejare, M. Ayodele, and E. De Langhe. 1990a. Shoot-tip culture and third-country quarantine to facilitate the introduction of new Musa germplasm into W. Africa. Plant Genet. Resources Nwsl. No. 81/82: 5- 11. Food and Agr. Organization/Intl. Board for Plant Genet. Resources, Rome. Vuylsteke, D., R. Swennen, and E. De Langhe. 1990b. Tissue culture technology for the improvement of African plantains, p. 3 16-337. In: R.A. Fullerton and R.H, Stover (eds.). Sigatoka leaf spot diseases of bananas, Pmt. Ind. Wkshp., San José, Costa Rica, 28 Mar- 1 Apr. 1989. Intl. Network for the Improvement of Banana and Plantain, Montpellier, France.

Vuylsteke, D.,R. Swennen, and E. De Langhe. 1991. Somaclonal variation in plantains (Musa spp., AAB group) derived from shoot-tip culture, Fruits 46:429439.

Vuylsteke, D., R. Ortiz, C. Pasberg-Gauhl, F. Gauhl, C. Gold, S. Ferris, and P. Speijer. 1993a. Plantain and banana research at the Intl. Inst. of Tmp. Agr. HortScience 28: 873-874, 970-971.

Vuylsteke, D., R. Swennen, and R. Ortiz. 1993b. Development and performance of black sigatoka-resistant tetraploid hybrids of plantain (Musa spp., AAB group). Euphytica 65:3342. 